\title{
Characterisation of the photolytic HONO-source in the atmosphere simulation chamber SAPHIR
}

\author{
F. Rohrer ${ }^{1}$, B. Bohn ${ }^{1}$, T. Brauers ${ }^{1}$, D. Brüning ${ }^{1}$, F.-J. Johnen ${ }^{1}$, A. Wahner ${ }^{1}$, and J. Kleffmann ${ }^{2}$ \\ ${ }^{1}$ Institut für Chemie und Dynamik der Geosphäre II: Troposphäre, Forschungszentrum Jülich, Jülich, Germany \\ ${ }^{2}$ Physikalische Chemie/FB C, Bergische Universität Wuppertal, Wuppertal, Germany \\ Received: 11 August 2004 - Published in Atmos. Chem. Phys. Discuss.: 3 December 2004 \\ Revised: 25 February 2005 - Accepted: 9 August 2005 - Published: 12 August 2005
}

\begin{abstract}
HONO formation has been proposed as an important $\mathrm{OH}$ radical source in simulation chambers for more than two decades. Besides the heterogeneous HONO formation by the dark reaction of $\mathrm{NO}_{2}$ and adsorbed water, a photolytic source has been proposed to explain the elevated reactivity in simulation chamber experiments. However, the mechanism of the photolytic process is not well understood so far. As expected, production of $\mathrm{HONO}$ and $\mathrm{NO}_{\mathrm{x}}$ was also observed inside the new atmospheric simulation chamber SAPHIR under solar irradiation. This photolytic $\mathrm{HONO}$ and $\mathrm{NO}_{\mathrm{x}}$ formation was studied with a sensitive $\mathrm{HONO}$ instrument under reproducible controlled conditions at atmospheric concentrations of other trace gases. It is shown that the photolytic HONO source in the SAPHIR chamber is not caused by $\mathrm{NO}_{2}$ reactions and that it is the only direct $\mathrm{NO}_{\mathrm{y}}$ source under illuminated conditions. In addition, the photolysis of nitrate which was recently postulated for the observed photolytic HONO formation on snow, ground, and glass surfaces, can be excluded in the chamber. A photolytic HONO source at the surface of the chamber is proposed which is strongly dependent on humidity, on light intensity, and on temperature. An empirical function describes these dependencies and reproduces the observed $\mathrm{HONO}$ formation rates to within 10 $\%$. It is shown that the photolysis of HONO represents the dominant radical source in the SAPHIR chamber for typical tropospheric $\mathrm{O}_{3} / \mathrm{H}_{2} \mathrm{O}$ concentrations. For these conditions, the HONO concentrations inside SAPHIR are similar to recent observations in ambient air.
\end{abstract}

Correspondence to: J. Kleffmann

(kleffman@uni-wuppertal.de)

\section{Introduction}

Nitrous acid (HONO) is of particular importance in atmospheric chemistry, since the photolysis of HONO:

$\mathrm{HONO} \stackrel{h v}{\longrightarrow} \mathrm{NO}+\mathrm{OH}$,

represents an important $\mathrm{OH}$ radical source (Harris et al., 1982; Harrison et al., 1996). Recent studies (Alicke et al., 2002, 2003; Aumont et al., 2003; Kleffmann, 2005; Ren et al., 2003; Vogel et al., 2003; Zhou et al., 2002a) calculated a significant contribution of the HONO photolysis to the integrated $\mathrm{OH}$ yield of up to $60 \%$. Furthermore, $\mathrm{HONO}$ is an important indoor pollutant, which can react with amines leading to nitrosamines, which are known to be carcinogenic (Pitts et al., 1978).

Besides in the atmosphere, nitrous acid is also an important precursor for $\mathrm{OH}$ radicals in simulation chambers (e.g. Carter et al., 1981), which have been used for many years to study atmospheric chemistry processes. In previous chamber studies a significant $\mathrm{OH}$ production was found which could not be attributed to known precursors. To explain this $\mathrm{OH}$ production the photolysis of heterogeneously formed HONO was assumed to be responsible, at least in part, for this so called background reactivity in the chambers (Akimoto et al., 1987; Carter et al., 1982; Glasson and Dunker, 1989; Killus and Whitten, 1990; Sakamaki and Akimoto, 1988). It was postulated that HONO is formed by two processes,

a) the heterogeneous dark Reaction (R2) of $\mathrm{NO}_{2}$ and water (e.g. Carter et al., 1981; Carter et al., 1982; FinlaysonPitts et al., 2003; Jenkin et al., 1988; Kleffmann et al., 1998; Pitts et al., 1984; Sakamaki et al., 1983; Svensson et al., 1987) responsible for the initiation of photosmog reactions and

$2 \mathrm{NO}_{2}+\mathrm{H}_{2} \mathrm{O} \longrightarrow \mathrm{HONO}+\mathrm{HNO}_{3}$, 
b) a photoenhanced HONO formation (R3) (Akimoto et al., 1987; Glasson and Dunker, 1989; Killus and Whitten, 1990; Sakamaki and Akimoto, 1988; Wang et al., 2000), to explain elevated reactivity under irradiation.

$\mathrm{Y}(\mathrm{HONO})+h v \longrightarrow \mathrm{HONO}$

The slower process, reaction R2, was studied and discussed in detail in a recent review article of Finlayson-Pitts et al. (2003) and will not be discussed in the present paper. However, the reaction mechanism of the photoenhanced HONO formation is not well understood. This process was quantified only indirectly by model calculations caused by missing direct measurements. Since in some studies the radical source strength increased with increasing humidity, radiation and with $\mathrm{NO}_{2}$ concentration, a photoenhanced reaction of $\mathrm{NO}_{2}$ and water was postulated (Akimoto et al., 1987; Sakamaki and Akimoto, 1988). However, in the study by Glasson and Dunker (1989) no $\mathrm{NO}_{2}$ dependence was observed for the photoenhanced process. Killus and Whitten (1990) compared results from different simulation chambers and postulated that different surface properties might explain the differences. For Teflon surfaces a photoenhanced direct HONO source was postulated by the photolysis of nitrate adsorbed on the surface.

Besides simulation chambers, a photoenhanced HONO formation was recently proposed in the atmosphere over snow (Beine et al., 2001, 2002; Dibb et al., 2002; Honrath et al., 2002; Zhou et al., 2001) and on ground and vegetation surfaces (Kleffmann et al., 2002, 2003; Ren et al., 2003; Vogel et al., 2003; Zhou et al., 2002a), to explain high day-time concentrations of HONO. The photolytic HONO source was also identified on glass surfaces (Zhou et al., 2002b, 2003) and was explained by the direct photolysis of nitrate/nitric acid and secondary reactions of $\mathrm{NO}_{2}$.

In summary, the photolytic HONO formation, both in the atmosphere and in simulation chambers is not well understood up to now, although it is clearly important. Accordingly, this process was studied in the atmospheric simulation chamber SAPHIR at atmospheric conditions with a very sensitive HONO instrument. The experimental results were interpreted by box model calculations.

\section{Experimental}

\subsection{Description of the simulation chamber SAPHIR}

The atmospheric simulation chamber SAPHIR (Simulation of Atmospheric PHotochemistry in a large Reaction chamber) is located on the campus of the Forschungszentrum Jülich. It consists of twin wall FEP Teflon foils of $125 \mu \mathrm{m}$ and $250 \mu \mathrm{m}$ thickness. The space between the twin walls is flushed at all times with high purity air to prevent contamination from outside. The chamber is aligned in north-south direction and has a cylindrical shape with $5 \mathrm{~m}$ diameter, $20 \mathrm{~m}$ length, and $270 \mathrm{~m}^{3}$ volume. The surface to volume ratio is approximately $1 \mathrm{~m}^{-1}$. Synthetic air is prepared by evaporation of high purity (better than $99.9999 \%$ ) liquid $\mathrm{N}_{2}$ and $\mathrm{O}_{2}$. Exchange of air inside the chamber is done via two flow controller systems. The large one up to $500 \mathrm{~m}^{3} / \mathrm{h}$ is used to flush the chamber to reach clean starting conditions between experiments. The smaller one up to $15 \mathrm{~m}^{3} / \mathrm{h}$ is used to replenish the chamber during experiments from losses due to the sampling of instruments and due to leaks. The chamber is operated at approximately $80 \mathrm{~Pa}$ overpressure. Under these conditions, the replenishment flow is between 3 and $8 \mathrm{~m}^{3} / \mathrm{h}$. Characterisation experiments with $\mathrm{NO}, \mathrm{NO}_{2}, \mathrm{O}_{3}, \mathrm{H}_{2} \mathrm{O}$, and other species showed that the replenishment flow causes dilution of trace species inside the chamber which can be described by an exponential decay over more than two orders of magnitude until the detection limits of the instruments are reached. Humidity is introduced into the chamber by heating up high purity water (Milli-Q Gradient A10, Millipore Corp.) and mixing the water vapour to a large flow of synthetic air $\left(300 \mathrm{~m}^{3} / \mathrm{h}\right)$ until the desired level of humidity is reached inside the chamber. Therefore the process of humidification up to relative humidities of $80 \%$ takes between 30 to $60 \mathrm{~min}-$ utes of time. Minimum humidity at a dew point of $-50^{\circ} \mathrm{C}$ or 0.08 mbar of water can be reached when the chamber is flushed more than ten times its volume. The chamber can be exposed to sun light within $60 \mathrm{~s}$ by opening a shutter system which also protects the chamber from dangerous weather conditions. Photolysis frequencies inside the chamber are approximately $80 \%$ of their outside values due to shadowing from structural elements holding the shutter system and the Teflon foil. Additionally, a second shutter system equipped with a filter foil can be used to change the spectrum of sun light during exposure. The filter foil almost absorbs all light below $370 \mathrm{~nm}$ and has an increasing transmission from $<1 \%$ to $\sim 85 \%$ in the spectral range $370-420 \mathrm{~nm}$. Further details of the chamber will be explained elsewhere (Brauers et al., $\left.2005^{1}\right)$.

\subsection{Instrumentation}

For the measurement of nitrous acid (HONO) a new, very sensitive instrument (LOPAP: Long Path Absorption Photometer) was used, which is described in detail elsewhere (Heland et al., 2001; Kleffmann et al., 2002). Briefly, HONO is sampled in a stripping coil by a fast chemical reaction and converted into an azo dye which is photometrically detected in long path absorption inside a special Teflon tube. The instrument has an integrated time resolution of $\sim 5 \mathrm{~min}$, a detection limit of 1-2 pptV, and an accuracy of $10 \%$. Caused by the two-channel concept of the instrument all tested interferences including the combined one against $\mathrm{NO}_{2}$ and unknown

\footnotetext{
${ }^{1}$ Brauers, T., Johnen, F. J, Häseler, R., Rohrer, F., Bohn, B., Tillmann, R., Rodriguez Bares, S., and Wahner, A.: The Atmosphere Simulation Chamber SAPHIR: A Tool for the Investigation of Photochemistry, in preparation, 2005.
} 
semi-volatile diesel exhaust components (Gutzwiller et al., 2002) can be neglected (Kleffmann et al., 2002). In addition, sampling artefacts, such as heterogeneous HONO formation in sampling lines (as an example see Zhou et al., 2002b), are minimised by the use of an external sampling unit in which the two stripping coils are mounted and which can be placed directly in the atmosphere of interest. In a recent intercomparison campaign with a DOAS instrument in which the same air masses were analysed for the first time (Kleffmann et al., $2005^{2}$ ) an excellent agreement was obtained also for low concentrations of HONO during daytime. This is in contrast to intercomparison studies of other chemical detectors with the DOAS technique (Appel et al., 1990; Coe et al., 1997; Febo et al., 1996; Müller et al., 1999), which show large discrepancies during the day probably caused by unknown interferences. The measured and corrected interferences of the LOPAP instrument can account for up to $40 \%$ at low HONO concentrations (Kleffmann et al., 2005²).

For the first measurements the external sampling unit of the LOPAP instrument was directly installed in the SAPHIR chamber. For most of the experiments however, the inlet of the external sampling unit was connected to the northern corner of the chamber by a short PFA tubing $(10 \mathrm{~cm}, 4 \mathrm{~mm}$ i.d. $)$. In contrast to complex atmospheric mixtures (Kleffmann et al., 2002), sampling artefacts were found to be small for the low trace gas and relative high HONO concentrations during the experiments in the SAPHIR chamber.

$\mathrm{NO}$ and $\mathrm{NO}_{2}$ measurements were performed with a chemiluminescence analyser (ECO PHYSICS TR480) equipped with a photolytic converter (ECO PHYSICS PLC760). The $\mathrm{NO}_{\mathrm{x}}$ data were analysed as described by Rohrer et al. (1998). For a time resolution of $90 \mathrm{~s}$ the detection limits were 5 and $10 \mathrm{pptV}$ and the accuracies 5 and $10 \%$ for $\mathrm{NO}$ and $\mathrm{NO}_{2}$, respectively. Since HONO mixing ratios were often higher than $\mathrm{NO}_{2}$ mixing ratios in the chamber, the HONO interference of the photolytic conversion system for $\mathrm{NO}_{2}$ is an important factor (for example see Fig. 1). This interference of $15 \%$ has been determined experimentally by using a pure HONO source similar to that described by Taira and Kanda (1990) quantified by the LOPAP instrument. Ozone was measured with a time resolution of $90 \mathrm{~s}$ by an UV absorption spectrometer (ANSYCO model O341M). The detection limit and accuracy was $0.5 \mathrm{ppbV}$ and 5\%, respectively. Photolysis frequencies were determined with a spectroradiometer (as described by Hofzumahaus et al., 1999) on the roof of the building beside the SAPHIR chamber with a time resolution of $2 \mathrm{~min}$. To account for shadowing effects of structural elements of the chamber, the photolysis frequency data were corrected with the help of numerical calculations (Bohn and Zilken, 2005; Bohn et al., 2005), leading to an accuracy

\footnotetext{
${ }^{2}$ Kleffmann, J., Lörzer, J. C., Wiesen, P., Trick, S., Volkamer, R., Rodenas, M., and Wirtz, K.: Intercomparisons of the DOAS and LOPAP Techniques for the Detection of Nitrous Acid (HONO) in the Atmosphere, manuscript in preparation, 2005.
}

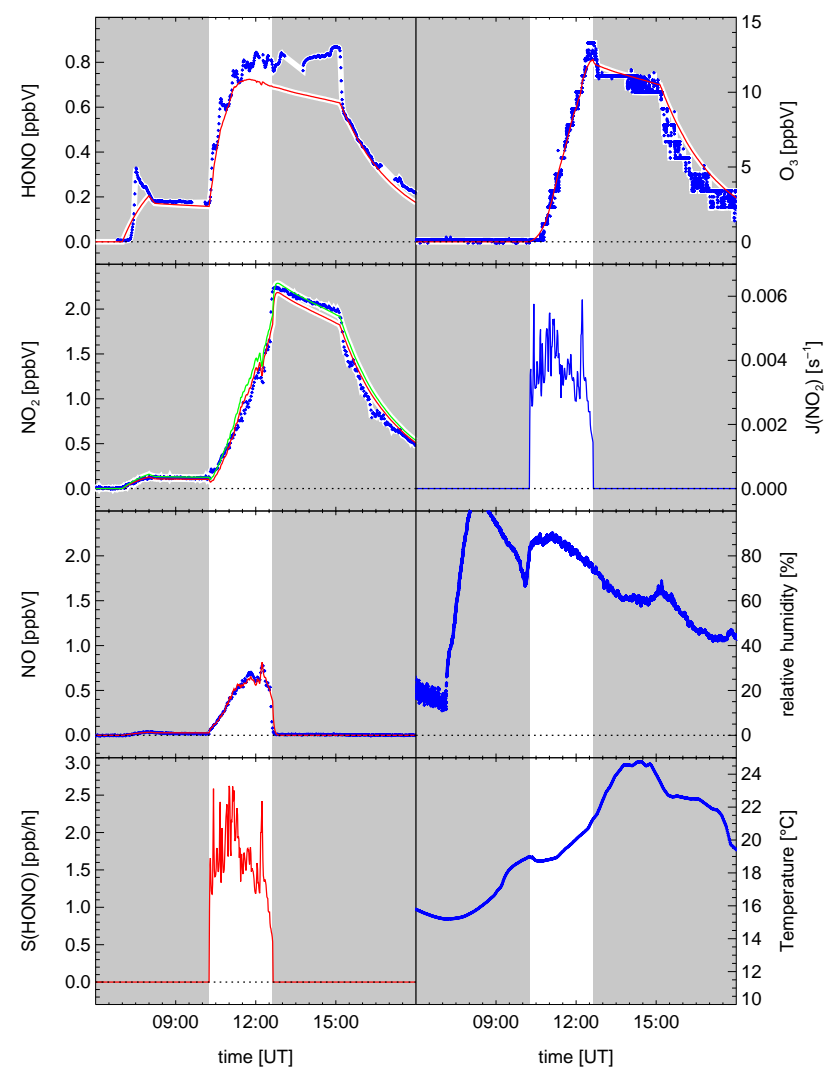

Fig. 1. HONO, $\mathrm{NO}_{\mathrm{x}}$, and ozone formation in SAPHIR illuminated with sunlight on August 08, 2001 (experiment type B, see Table 1). In the time interval between 07:00 and 08:30 UT, small amounts of $\mathrm{HONO}$ and $\mathrm{NO}_{2}$ were flushed into the chamber during the humidification process. Blue symbols mark observations, red and green lines show the result of model calculations (see text). The shaded areas mark the time periods were the chamber was not illuminated.

of $10 \%$. Humidity was determined with a frost point hygrometer (General Eastern model Hygro M4) and air temperature by an ultra sonic anemometer (Metek USA-1, accuracy $0.3 \mathrm{~K}$ ).

Several cross checks of the instrumentation were performed to examine the consistency of the data sets. The pure HONO source was analysed by the LOPAP instrument and by the $\mathrm{NO}_{\mathrm{x}}$ instrumentation by using a catalytic conversion system for $\mathrm{NO}_{\mathrm{y}}$ as described by Fahey et al. (1985). Both instruments showed agreement within 5\%. A second test was performed by introducing $50 \mathrm{ppbV}$ of $\mathrm{NO}_{2}$ into the chamber with closed shutters. After exposure to sunlight and photolysis of $\mathrm{NO}_{2}$ yielding equal amounts of $\mathrm{NO}$ and ozone, the $\mathrm{NO}$ and ozone instruments showed consistency within $2 \%$. Moreover, the photostationary state of $\mathrm{NO}$, ozone, and $\mathrm{NO}_{2}$ reached after exposure with light was consistent within $10 \%$ with the measured photolysis frequency $\mathrm{J}\left(\mathrm{NO}_{2}\right)$ and the recommended literature value for the rate constant of the reaction of NO with ozone (Sander et al., 2003). 


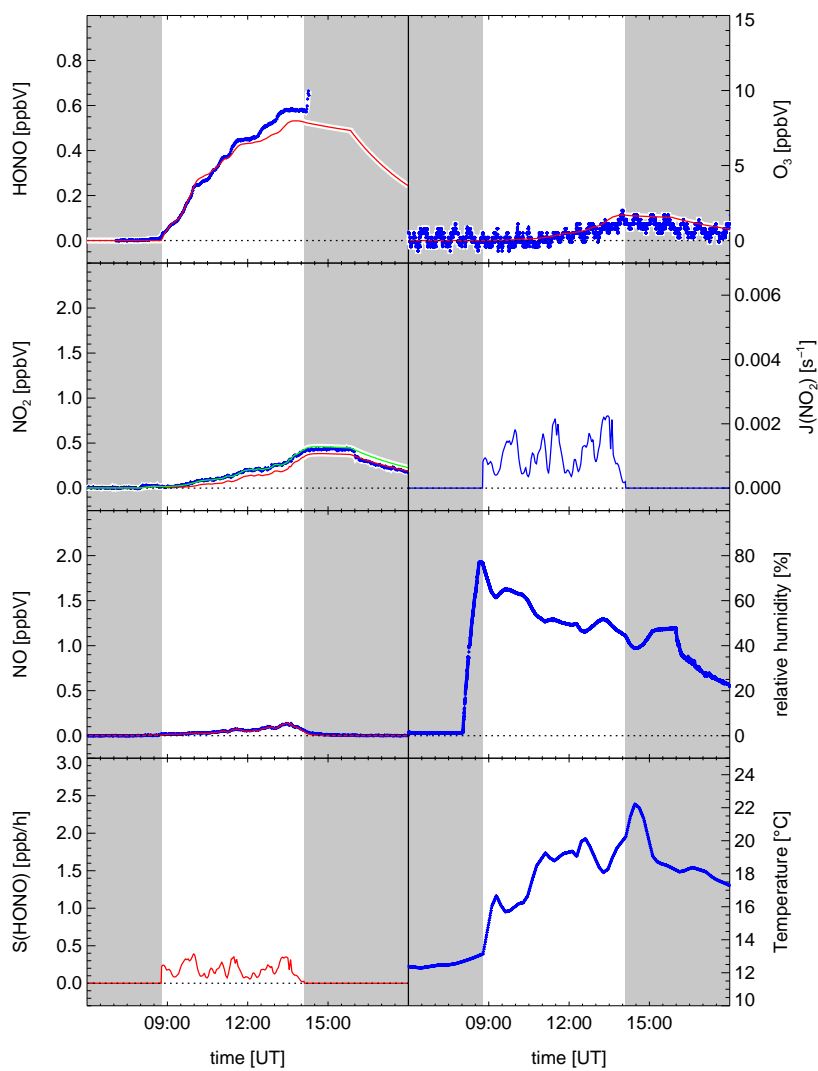

Fig. 2. HONO, $\mathrm{NO}_{\mathrm{x}}$, and ozone formation in SAPHIR illuminated with sunlight using an additional filter foil in the presence of 550 ppmV of CO on 2 July 2002 (experiment type D, see Table 1). Blue symbols mark observations, red and green lines show the result of model calculations (see text). The shaded areas mark the time periods were the chamber was not illuminated.

\section{Measurement concept}

The illuminated atmosphere simulation chamber SAPHIR generates $\mathrm{HONO}, \mathrm{NO}_{\mathrm{x}}$, and $\mathrm{O}_{3}$. For most experimental conditions the HONO concentration originating from this process is large enough so that $\mathrm{OH}$ production via HONO photolysis is significant for the interpretation of simulation experiments. Therefore, a series of dedicated experiments has been designed to determine reproducibility and dependencies on boundary conditions for the characterization of HONO and $\mathrm{NO}_{\mathrm{x}}$ production in SAPHIR. These experiments consist of three parts: a) preparation of initial conditions, b) illumination with solar irradiation, and c) interpretation of results. The preparation of initial conditions is started by flushing the chamber with high purity air for a long enough time so that all measured species are close to their detection limit. For some of the experiments relative humidity, $\mathrm{CO}$, or $\mathrm{NO}_{\mathrm{x}}$ concentrations are adjusted to preselected values to determine the production rates of $\mathrm{HONO}$ and $\mathrm{NO}_{\mathrm{x}}$ for these conditions. Variation of temperature is limited to natural variabil- ity and changed between $280-310 \mathrm{~K}$ during the experiments presented here. When initial conditions are adjusted, the roof of the chamber is opened so that the air sample in the chamber is illuminated. The temperature in the chamber is only slightly changed when the chamber is irradiated (ca. $+1 \mathrm{~K}$, see Figs. 1 and 2). The time series of $\mathrm{NO}_{\mathrm{x}}, \mathrm{O}_{3}$, humidity, temperature, and of photolysis frequencies are monitored for all of these experiments. The variation of HONO is measured also for some of the experiments depending on availability of the detection system. After a few hours of solar illumination, the roof is closed finishing the experiment. The interpretation of the experiments is done with the help of a photochemical model. The parameters of the model describing the generation of HONO are adjusted so that the measured time responses of $\mathrm{NO}_{\mathrm{x}}$ and $\mathrm{O}_{3}$ are reproduced. If available the measured HONO concentrations are also used to check for consistency with model assumptions.

\section{Results}

\subsection{Dedicated experiments in the SAPHIR chamber}

For most of the experiments presented here, the SAPHIR chamber was flushed by synthetic air overnight until the trace gas concentrations were below the detection limits of the instruments. Afterwards, initial conditions for humidity were adjusted. When the SAPHIR chamber was exposed to sun light the instantaneous formation of HONO and other trace gases like $\mathrm{NO}, \mathrm{NO}_{2}$, and $\mathrm{O}_{3}$ was observed (see Figs. 1 and 2). For "clean" conditions, no formation of these trace species was observed without illumination. But in several experiments (for example Fig. 1), small amounts of HONO and $\mathrm{NO}_{2}$ were detected in the dark chamber associated only with the process of humidification. This artefact was observed when the humidifier had not been operated for some time. In some of the experiments, $550 \mathrm{ppmV}$ of $\mathrm{CO}$ were injected into the chamber to suppress $\mathrm{OH}$ concentrations below $10^{4} \mathrm{~cm}^{-3}$. Under these conditions, the interpretation of the budgets of $\mathrm{NO}_{\mathrm{x}}$ and $\mathrm{HONO}$ was very much simplified because only production of HONO, photolysis of HONO and dilution of $\mathrm{HONO}$ and $\mathrm{NO}_{\mathrm{x}}$ had to be taken into account. In a single dedicated experiment, $30 \%$ relative humidity and an initial $\mathrm{NO}_{2}$ mixing ratio of $35 \mathrm{ppbV}$ were used to search especially for a $\mathrm{NO}_{2}$ enhanced $\mathrm{HONO}$ formation. Overall, 5 different experimental conditions summarised in Tables 1 and 2 were used to characterise HONO emissions in SAPHIR in the time period between 07/2001 and 12/2003.

In these experiments, typical HONO concentrations under irradiation were in the region of several $100 \mathrm{pptV}$ for high humidities of $>10 \%$ RH (see Figs. 1 and 2) and several $10 \mathrm{pptV}$ for low humidities at dew points of $-40^{\circ} \mathrm{C}$. The dominant influence of irradiation and humidity on HONO production rates was therefore obvious. To further study the photoenhanced HONO formation in the SAPHIR chamber, 
Table 1. Overview about the different types of HONO characterisation experiments.

\begin{tabular}{cccccc}
\hline Experiment Type & Relative Humidity & $\mathrm{CO}$ & Initial $\mathrm{NO}_{2}$ & Filter foil & Number of analysed experiments \\
\hline $\mathrm{A}$ & $<1 \%$ & 0 & 0 & - & 11 \\
$\mathrm{~B}$ & $>10 \%$ & 0 & 0 & - & 9 \\
$\mathrm{C}$ & $>10 \%$ & $550 \mathrm{ppmV}$ & 0 & - & 2 \\
$\mathrm{D}$ & $>10 \%$ & $550 \mathrm{ppmV}$ & 0 & + & 2 \\
$\mathrm{E}$ & $30 \%$ & 0 & $35 \mathrm{ppbV}$ & - & 1 \\
\hline
\end{tabular}

Table 2. Detailed experimental conditions for HONO characterisation experiments. HONO concentrations are taken from model calculations since not all experiments are accompanied by LOPAP HONO measurements due to limited availability.

\begin{tabular}{ccccccc}
\hline $\begin{array}{c}\text { Experiment } \\
\text { date_type }\end{array}$ & $\begin{array}{c}\mathrm{T}_{\min } \\
{ }^{\circ} \mathrm{C}\end{array}$ & $\begin{array}{c}\mathrm{T}_{\max } \mathrm{C} \\
{ }^{\circ}\end{array}$ & $\begin{array}{c}\mathrm{RH}_{\max } \\
\text { \% }\end{array}$ & $\begin{array}{c}\mathrm{HONO} \\
\mathrm{ppb}\end{array}$ & $\begin{array}{c}\mathrm{S}(\mathrm{HONO})_{\max } \\
\mathrm{ppb} / \mathrm{h}\end{array}$ & $\begin{array}{c}\mathrm{J}\left(\mathrm{NO}_{2}\right)_{\max } \\
10^{-3} \mathrm{~s}^{-1}\end{array}$ \\
\hline 250701_A & 30.0 & 34.0 & $<1$ & 0.025 & 0.104 & 9.7 \\
300701_A & 30.0 & 34.0 & $<1$ & 0.018 & 0.077 & 9.6 \\
020801_A & 28.0 & 32.0 & $<1$ & 0.014 & 0.051 & 9.6 \\
070801_A & 18.0 & 22.0 & $<1$ & 0.017 & 0.075 & 10.2 \\
080801_B & 18.7 & 21.3 & 89.9 & 0.725 & 2.624 & 7.4 \\
040901_A & 31.8 & 34.6 & 0.4 & 0.011 & 0.044 & 7.6 \\
020202_B & 12.4 & 19.9 & 82.5 & 0.337 & 0.704 & 3.3 \\
270302_A & 12.0 & 16.0 & $<1$ & 0.012 & 0.033 & 6.5 \\
040202_E & 10.0 & 12.2 & 36.7 & 0.320 & 0.156 & 3.6 \\
280302_A & 12.0 & 16.0 & $<1$ & 0.006 & 0.016 & 6.8 \\
010702_C & 15.8 & 16.9 & 67.2 & 0.402 & 0.665 & 2.5 \\
020702_D & 13.1 & 20.2 & 76.9 & 0.532 & 0.391 & 2.3 \\
040702_B & 15.6 & 25.6 & 72.7 & 0.379 & 0.966 & 7.0 \\
050702_B & 22.6 & 27.2 & 60.7 & 0.525 & 2.225 & 6.6 \\
080702_D & 21.9 & 37.8 & 60.6 & 0.913 & 2.648 & 2.2 \\
090702_B & 23.2 & 32.1 & 57.9 & 0.426 & 0.726 & 5.3 \\
130802_A & 22.0 & 28.0 & $<1$ & 0.027 & 0.134 & 3.8 \\
300902_B & 13.7 & 23.8 & 41.6 & 0.349 & 1.039 & 4.5 \\
260503_A & 17.0 & 27.0 & 0.6 & 0.110 & 0.210 & 7.9 \\
270503_B & 19.9 & 29.2 & 48.2 & 0.470 & 1.668 & 6.1 \\
070603_A & 21.2 & 32.9 & 0.7 & 0.080 & 0.200 & 5.9 \\
120603_A & 18.3 & 32.6 & 0.9 & 0.075 & 0.184 & 6.2 \\
110703_B & 22.0 & 33.2 & 35.1 & 0.224 & 0.720 & 6.4 \\
190903_B & 22.1 & 33.2 & 46.6 & 0.542 & 1.456 & 4.2 \\
220903_C & 23.7 & 36.1 & 27.9 & 0.159 & 0.413 & 4.4 \\
\hline
\end{tabular}

the spectral range of the radiation inside the chamber was varied. For this purpose HONO formation was studied under humid conditions when light at short wavelengths $(<370 \mathrm{~nm})$ was absorbed outside the Teflon chamber by the use of the filter foil. The photolysis frequency of $\mathrm{NO}_{2}, \mathrm{~J}\left(\mathrm{NO}_{2}\right)$, decreased by a factor of $\sim 3$ by the filter foil, $\mathrm{J}(\mathrm{HONO})$ by a factor of 10 , and the photolysis frequency of ozone, $\mathrm{J}\left(\mathrm{O}^{1} \mathrm{D}\right)$, decreased by a factor of 100 . Nevertheless, when the filter foil was used, still a significant HONO formation was observed under irradiation (see Fig. 2). But there is a significant difference between the experiments with and without the filter foil in Figs. 1 and 2. Since both, the production of $\mathrm{HONO}$ (which is proportional to $\mathrm{J}\left(\mathrm{NO}_{2}\right)$ ) and the destruction of HONO via $\mathrm{J}(\mathrm{HONO})$ are reduced by the filter foil, the slope of the HONO increase is very much reduced in the experiment shown in Fig. 2 although the maximum HONO concentrations are similar in both experiments. The main difference is therefore the maximum $\mathrm{NO}_{\mathrm{x}}$ concentration which is very low for the experiment in Fig. 2 with reduced $\mathrm{J}(\mathrm{HONO})$.

\subsection{Model calculations}

In order to quantify the $\mathrm{HONO}$ production rate $\mathrm{S}(\mathrm{HONO})_{\text {SAPHIR }}$ under various conditions model 
Table 3. Reaction scheme used for the model calculation with reaction constants taken from Sander et al. (2003).

\begin{tabular}{|c|c|c|}
\hline $\mathrm{O}^{1} \mathrm{D}+\mathrm{O}_{2}$ & $\longrightarrow$ & $\mathrm{O}_{3}$ \\
\hline $\mathrm{NO}+\mathrm{O}_{3}$ & $\longrightarrow$ & $\mathrm{NO}_{2}$ \\
\hline $\mathrm{O}^{1} \mathrm{D}+\mathrm{N}_{2}$ & $\longrightarrow$ & $\mathrm{O}_{3}$ \\
\hline $\mathrm{NO}+\mathrm{OH}$ & $\longrightarrow$ & $\mathrm{HNO}_{2}$ \\
\hline $\mathrm{O}^{1} \mathrm{D}+\mathrm{H}_{2} \mathrm{O}$ & $\longrightarrow$ & $2 \cdot \mathrm{OH}$ \\
\hline $\mathrm{NO}_{2}+\mathrm{NO}_{3}$ & $\longrightarrow$ & $\mathrm{N}_{2} \mathrm{O}_{5}$ \\
\hline $2 \cdot \mathrm{HO}_{2}$ & $\longrightarrow$ & $\mathrm{H}_{2} \mathrm{O}_{2}$ \\
\hline $\mathrm{NO}_{2}+\mathrm{O}_{3}$ & $\longrightarrow$ & $\mathrm{NO}_{3}$ \\
\hline $2 \cdot \mathrm{HO}_{2}+\mathrm{H}_{2} \mathrm{O}$ & $\longrightarrow$ & $\mathrm{H}_{2} \mathrm{O}_{2}$ \\
\hline $\mathrm{NO}_{2}+\mathrm{OH}$ & $\longrightarrow$ & $\mathrm{HNO}_{3}$ \\
\hline $\mathrm{CO}+\mathrm{OH}$ & $\longrightarrow$ & $\mathrm{CO}_{2}+\mathrm{HO}_{2}$ \\
\hline $\mathrm{NO}_{3}+\mathrm{OH}$ & $\longrightarrow$ & $\mathrm{HO}_{2}+\mathrm{NO}_{2}$ \\
\hline $\mathrm{H}_{2}+\mathrm{OH}$ & $\longrightarrow$ & $\mathrm{HO}_{2}$ \\
\hline $\mathrm{O}_{3}+\mathrm{OH}$ & $\longrightarrow$ & $\mathrm{HO}_{2}$ \\
\hline $\mathrm{H}_{2} \mathrm{O}_{2}+\mathrm{OH}$ & $\longrightarrow$ & $\mathrm{H}_{2} \mathrm{O}+\mathrm{HO}_{2}$ \\
\hline $\mathrm{HNO}_{2}+h v$ & $\longrightarrow$ & $\mathrm{NO}+\mathrm{OH}$ \\
\hline $\mathrm{HCHO}+\mathrm{OH}$ & $\longrightarrow$ & $\mathrm{CO}+\mathrm{HO}_{2}$ \\
\hline $\mathrm{H}_{2} \mathrm{O}_{2}+h v$ & $\longrightarrow$ & $2 \cdot \mathrm{OH}$ \\
\hline $\mathrm{HNO}_{2}+\mathrm{OH}$ & $\longrightarrow$ & $\mathrm{H}_{2} \mathrm{O}+\mathrm{NO}_{2}$ \\
\hline $\mathrm{HCHO}+h v$ & $\longrightarrow$ & $\mathrm{CO}+2 \cdot \mathrm{HO}_{2}$ \\
\hline $\mathrm{HNO}_{3}+\mathrm{OH}$ & $\longrightarrow$ & $\mathrm{H}_{2} \mathrm{O}+\mathrm{NO}_{3}$ \\
\hline $\mathrm{HCHO}+h v$ & $\longrightarrow$ & $\mathrm{CO}+\mathrm{H}_{2}$ \\
\hline $\mathrm{HO}_{2}+\mathrm{NO}$ & $\longrightarrow$ & $\mathrm{NO}_{2}+\mathrm{OH}$ \\
\hline $\mathrm{NO}_{2}+h v$ & $\longrightarrow$ & $\mathrm{NO}+\mathrm{O}_{3}$ \\
\hline $\mathrm{HO}_{2}+\mathrm{NO}_{3}$ & $\longrightarrow$ & $\mathrm{NO}_{2}+\mathrm{OH}$ \\
\hline $\mathrm{NO}_{3}+h v$ & $\longrightarrow$ & $\mathrm{NO}$ \\
\hline $\mathrm{HO}_{2}+\mathrm{O}_{3}$ & $\longrightarrow$ & $\mathrm{OH}$ \\
\hline $\mathrm{NO}_{3}+h v$ & $\longrightarrow$ & $\mathrm{NO}_{2}+\mathrm{O}_{3}$ \\
\hline $\mathrm{HO}_{2}+\mathrm{OH}$ & $\longrightarrow$ & $\mathrm{H}_{2} \mathrm{O}$ \\
\hline $\mathrm{O}_{3}+h v$ & $\longrightarrow$ & $\mathrm{O}^{1} \mathrm{D}$ \\
\hline $\mathrm{N}_{2} \mathrm{O}_{5}$ & $\longrightarrow$ & $\mathrm{NO}_{2}+\mathrm{NO}_{3}$ \\
\hline
\end{tabular}

calculations were performed using the photochemical reaction scheme outlined in Table 3 describing a simple $\mathrm{NO}_{\mathrm{x}} / \mathrm{HONO} / \mathrm{CO} / \mathrm{HCHO}$ chemistry with reaction constants taken from Sander et al. (2003). In addition, Reactions (R3) (see introduction), (R4), (R5) and (R6) were introduced into the model to account for several phenomena observed in SAPHIR:

$$
\begin{aligned}
& \mathrm{OH}+\mathrm{X} \longrightarrow \mathrm{HO}_{2} \quad k=k(\mathrm{CO}+\mathrm{OH}) \\
& \text { all tracers } \longrightarrow \quad k=\text { flow } / \text { volume } \\
& \mathrm{Y}(\mathrm{HCHO})+h v \longrightarrow \mathrm{HCHO} \quad \text { rate }: 0-0.2 \mathrm{ppb} / \mathrm{h}
\end{aligned}
$$

Reaction (R3) describes the observation of photolytically induced HONO formation. In addition, to simulate the small increases of $\mathrm{NO}_{2}$ and $\mathrm{HONO}$ during some humidification processes in the dark chamber, appropriate amounts of $\mathrm{NO}_{2}$ and HONO were introduced into the model calculations also (see Fig. 1). Reaction R4 accounts for the phenomenon that even with very clean starting conditions when all measured
Table 4. Result of fitting the observed time series of $\mathrm{NO}$ and $\mathrm{NO}_{2}$ for the experiments mentioned in Tables 1 and 2 to model calculations using the parameterisation (1).

\begin{tabular}{cccc}
\hline Time period & $a_{i}$ & $R H_{0}$ & $T_{0}$ \\
\hline $07 / 2001-07 / 2002$ & $4.7 \times 10^{13} \mathrm{~cm}^{-3}$ & $11.6 \%$ & $3950 \mathrm{~K}$ \\
$08 / 2002-12 / 2003$ & $8.5 \times 10^{13} \mathrm{~cm}^{-3}$ & $11.6 \%$ & $3950 \mathrm{~K}$ \\
\hline
\end{tabular}

NMHCs are below their detection limit immediate ozone formation is observed when the chamber is illuminated. All measured species like $\mathrm{CO}$ and NMHCs are below their detection limits at the beginning of the experiments. For this reason an unknown species $\mathrm{X}$ was introduced in the chemical mechanism which can react with $\mathrm{OH}$ giving $\mathrm{HO}_{2}$. Subsequent reaction of $\mathrm{HO}_{2}$ with $\mathrm{NO}$ gives the desired ozone formation. To facilitate comparisons, the reaction constant of $\mathrm{CO}$ with $\mathrm{OH}$ from Sander et al. (2003) was used as a parameter for Reaction (R4). Reactions similar to (R5) were introduced for all trace species in the reaction mechanism to describe dilution by the replenishment flow as first order loss reactions. The reaction constant was calculated from the volume of the chamber and the measured replenishment flow. Reaction (R6) is necessary to follow the observed HCHO production when the chamber is illuminated. The HCHO formation was linear with time and depending on humidity, light intensity and temperature. The rate of $\mathrm{HCHO}$ formation used in the model was adjusted to the measured rate. However, this reaction has only marginal influence on the $\mathrm{HO}_{\mathrm{x}}$ budget in the chamber and is given here only for completeness. The characterisation of the HCHO source in the SAPHIR chamber will be described in a forthcoming paper.

Subsequent model calculations showed that the following empirically derived parameterisation for the production rate of $\mathrm{HONO}$ describes the observed time series of $\mathrm{NO}$ and $\mathrm{NO}_{2}$ :

$$
\begin{aligned}
& S(\mathrm{HONO})_{\mathrm{SAPHIR}, i}=a_{i} \times \mathrm{J}\left(\mathrm{NO}_{2}\right) \times\left(1+\left(R H / R H_{0}\right)^{2}\right) \times e^{-T_{0} / T} \\
& {\left[\mathrm{~cm}^{-3} \mathrm{~s}^{-1}\right] \quad i=1,2}
\end{aligned}
$$

$T$ represents the temperature in $\mathrm{K}, R H$ the relative humidity in $\%, \mathrm{~J}\left(\mathrm{NO}_{2}\right)$ the photolysis frequency of $\mathrm{NO}_{2}$ in $\mathrm{s}^{-1}$ and $a_{i}$, $R H_{0}$ and $T_{0}$ are fitting parameters specified in Table 4. Equation (1) is an empirical function with only three parameters which is able to describe the HONO formation in SAPHIR with good precision for a broad band of boundary conditions. This is a significant step forward in the process of using the simulation chamber SAPHIR as a tool for investigation of atmospheric chemistry. Equation (1) is not based on a physical model of the processes controlling HONO formation in SAPHIR.

To find the optimum set of parameters for Eq. (1), humidity, temperature, and $\mathrm{J}\left(\mathrm{NO}_{2}\right)$ were used as observed. The concentrations of the unknown species X for Reaction (R4) 


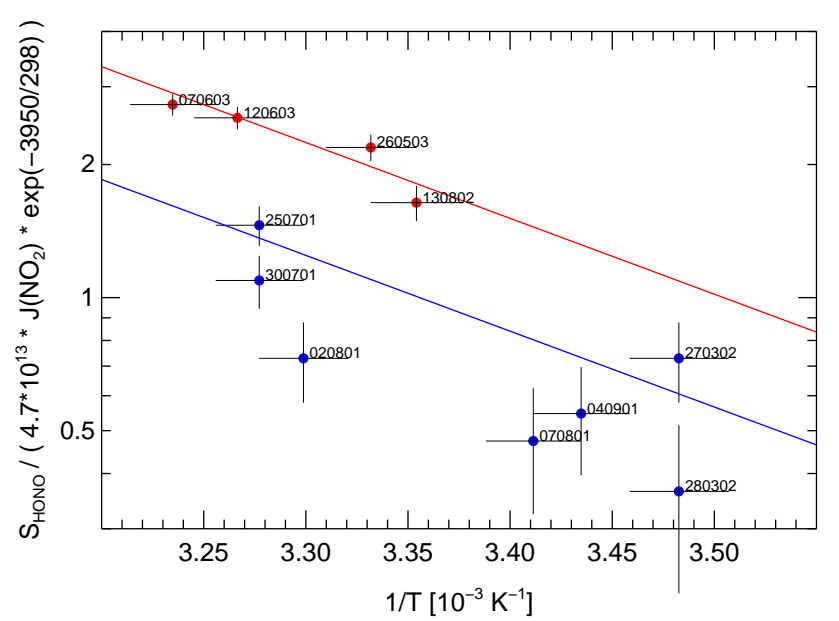

Fig. 3. Dependence of $\mathrm{S}(\mathrm{HONO})_{\mathrm{SAPHIR}}$ on $1 / \mathrm{T}$ determined from the fit of Eq. (1) to observed time series of $\mathrm{NO}$ and $\mathrm{NO}_{2}$ for the experiments type $\mathrm{A}$ in Table 1 with relative humidities below $1 \%$. Indicated is the date of experiments in the form DDMMYY. $\mathrm{S}(\mathrm{HONO})_{\text {SAPHIR }}$ has been scaled with $\mathrm{J}\left(\mathrm{NO}_{2}\right)$. The blue dots mark experiments before August, 2002, the red dots those after that date. The blue and red lines represent Eq. (1) with parameters given in Table 4.

were chosen independently for each experiment to explain the measured ozone concentrations. The value of $\mathrm{X}$ varied between 100 and $300 \mathrm{ppbV}$ of $\mathrm{CO}$ equivalents. Its variation could not be attributed to a particular process.

The parameters $a_{i}, R H_{0}$ and $T_{0}$ were then optimised by fitting the observed $\mathrm{NO}$ and $\mathrm{NO}_{2}$ mixing ratios of the experiments listed in Table 1 to model calculations with the help of the Levenberg-Marquard algorithm. The results of these calculations are shown in Figs. 1 and 2 as red lines. The green lines describe the calculated $\mathrm{NO}_{2}$ time series including $15 \%$ of the calculated $\mathrm{HONO}$ mixing ratios to account for the HONO interference of the detection system for $\mathrm{NO}_{2}$ (see Sect. 2.2). Two sets of parameters were determined. The experiments before August 2002, could be explained by one set of parameters, the experiments after that date by another set of parameters. The parameters $a_{1}$ and $a_{2}$ describe the difference between both sets of experiments which is a factor of 1.8. The time frame for this change is defined by the experiments of 9 July and 13 August 2002. Between these limiting HONO experiments, several other experiments were performed in the chamber namely ozonolysis of alkenes and actinometric experiments with $30 \mathrm{ppbV}$ of $\mathrm{NO}_{2}$. However, these types of experiments were also conducted before and after that time frame. Therefore the reason for the sudden change in the photoenhanced emission rate of HONO remains unknown. Table 4 summarises these results.

Figure 3 shows normalised values of $\mathrm{S}(\mathrm{HONO})$ as a function of $1 / \mathrm{T}$ for the experiments with relative humidities of less than $1 \%$. $\mathrm{S}(\mathrm{HONO})$ was normalised with $\mathrm{J}\left(\mathrm{NO}_{2}\right)$ using

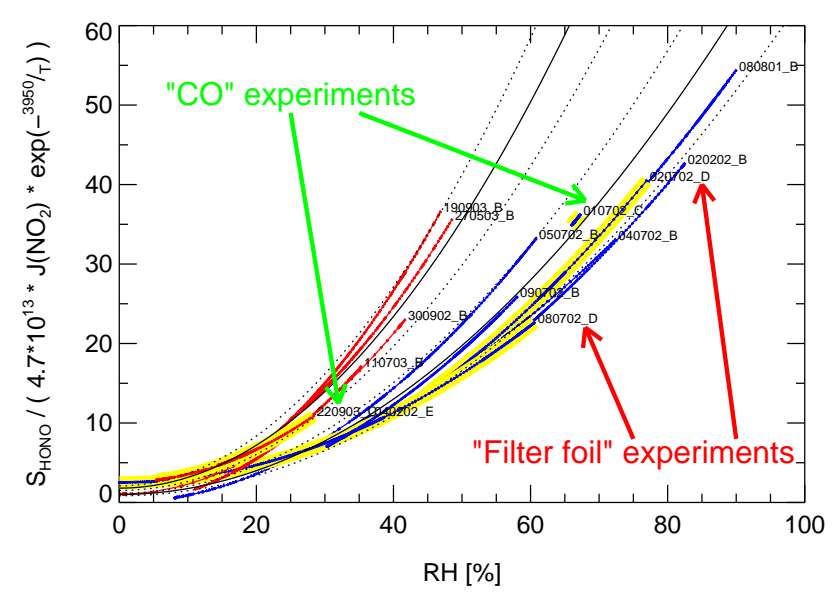

Fig. 4. Dependence of S(HONO) SAPHIR on relative humidity determined from the fit of Eq. (1) to observed time series of $\mathrm{NO}$ and $\mathrm{NO}_{2}$ for experiments $\mathrm{B}, \mathrm{C}, \mathrm{D}$, and $\mathrm{E}$ mentioned in Table 1 with relative humidities above $10 \%$. Indicated is the date of experiments in the form DDMMYY and the type of experiment. S(HONO) SAPHIR has been scaled with $\mathrm{J}\left(\mathrm{NO}_{2}\right)$ and the temperature function in Eq. (1) to separate the dependence on relative humidity. Blue lines mark experiments before 13 August 2002, red lines those after that date. The solid black lines represent Eq. (1) with parameters given in Table 4 . Dotted black lines indicate a region of $\pm 0.15 \times$ ordinate value above and below the solid black line. This region is defined by the spread of the individual experiments belonging to each of the two groups.

Eq. (1) to demonstrate the effect of temperature relative to a standard temperature of $298 \mathrm{~K}$. Since the relative humidity was very low, the humidity dependent term in Eq. (1) was not used in this normalization process. Both sets of experiments with different $a$ values are clearly distinguishable. The estimated uncertainty of the determination of a single HONO production rate of 0.15 is shown here as the vertical line at each data point. Horizontal lines mark the temperature range covered by each experiment.

Figure 4 shows normalised values of S(HONO) as a function of the relative humidity for the experiments started with relative humidities of more than $10 \%$. In this case, the data was normalised using the temperature and $\mathrm{J}\left(\mathrm{NO}_{2}\right)$ dependend terms in Eq. (1) to compare the remaining humidity dependence of $\mathrm{S}(\mathrm{HONO})$ in the different experiments. As in Fig. 3, both groups of experiments are clearly visible. Interestingly, the highlighted experiments with $550 \mathrm{ppmV} \mathrm{CO}$ or with the filter foil are well within the range of the other experiments. The values calculated with Eq. (1) with both sets of parameters in Table 4 are included in Fig. 4 as solid black lines. Dotted lines mark regions which are defined by the envelope embedding all of the individual experiments. This maximum spread of experiments in both groups is $\pm 15 \%$. The accuracy of Eq. (1) is therefore estimated to be on the order of $10 \%$. 


\section{Discussion}

In other studies, a photoenhanced background reactivity was proposed to explain elevated reactivity in simulation chambers under irradiation (Akimoto et al., 1987; Glasson and Dunker, 1989; Killus and Whitten, 1990; Sakamaki and Akimoto, 1988; Wang et al., 2000). However, in contrast to all known studies of the background reactivity of simulation chambers, HONO was unequivocally identified under illuminated conditions in the present study for the first time. We observed that the addition of CO had no effect on the HONO production. Since the addition of CO decreased the $\mathrm{OH}$ radical concentration by at least three orders of magnitude, formation of HONO by the gas phase reaction of $\mathrm{NO}$ and $\mathrm{OH}$ (see Table 2) is not of importance under our experimental conditions. The photolytic HONO source in SAPHIR was found to be proportional to the photolysis frequency of $\mathrm{NO}_{2}$, which is in good agreement with parameterisations of the background reactivity made in the study of Wang et al. (2000). In addition, the photolytic HONO source increased with the square of relative humidity and exponentially with temperature. A water dependence of the background reactivity was also observed in most other studies (Akimoto et al., 1987; Killus and Whitten, 1990; Sakamaki and Akimoto, 1988). The excellent agreement between experimental results and model calculation clearly shows that the photolytic HONO source is the dominant $\mathrm{NO}_{\mathrm{x}}$ source in the chamber, in good agreement with suggestions of Killus and Whitten (1990). In contrast, a direct photolytic $\mathrm{NO}_{\mathrm{x}}$ source which has recently be proposed for snow (Davis et al., 2001; Honrath et al., 1999, 2000; Jones et al., 2000, 2001) and glass surfaces (Zhou et al., 2002b, 2003) by the photolysis of nitrate can be excluded, since the modelled HONO concentration would be significantly higher than the measured one in this case.

In two older studies (Akimoto et al., 1987; Sakamaki and Akimoto, 1988), the elevated reactivity in simulation chambers under irradiation was explained by a photoenhancement of Reaction (2), $2 \mathrm{NO}_{2}+\mathrm{H}_{2} \mathrm{O}$, since the radical source strength increased with increasing humidity, radiation and $\mathrm{NO}_{2}$ concentration. In addition, the involvement of $\mathrm{NO}_{2}$ in the photoenhanced HONO formation was very recently observed on organic substrates (George et al., 2005). However, a photoenhancement of a $\mathrm{NO}_{2}$ reaction is considered unlikely for SAPHIR based on the results of the present study, since the majority of experiments started with very low $\mathrm{NO}_{2}$ concentrations on the order of $20 \mathrm{pptV}$ or less. During the course of these experiments, $\mathrm{NO}_{2}$ increased to several $100 \mathrm{pptV}$ without influence on the photolytic HONO formation (see Figs. 1 and 2 for example). In a dedicated experiment (experiment type $\mathrm{E}$, Table 1), $35 \mathrm{ppbV}$ of $\mathrm{NO}_{2}$ at $30 \%$ relative humidity was used as starting conditions again showing no enhancement on the photolytic HONO production. Since a monolayer adsorption of $\mathrm{NO}_{2}$ on the Teflon surface cannot be expected for a few pptV of $\mathrm{NO}_{2}$ in the gas phase, an in- crease of the $\mathrm{NO}_{2}$ concentration by three orders of magnitude should clearly have an influence on any $\mathrm{NO}_{2}$ surface reaction. Since this was not observed, these experiments showed that a photoenhancement of the reaction of $\mathrm{NO}_{2}$ with water vapour (Reaction $\mathrm{R} 2$ ) or of $\mathrm{NO}_{2}$ with adsorbed organic compounds are not of importance in SAPHIR. In addition, adsorption of HONO on the Teflon surface, formed during prior experiments by any $\mathrm{NO}_{2}$ reactions, can also be excluded. In this case, HONO should desorb from the walls when the humidity is increased in the dark, as observed in other chambers (e.g. Syomin and Finlayson-Pitts, 2003), in contrast to the SAPHIR chamber (see Fig. 2).

In the study of Killus and Whitten (1990) the photoenhancement of the background reactivity in Teflon chambers was explained by the photolysis of nitrate, since elevated reactivity was observed after experiments in which high nitric acid concentrations were used. The photolysis of nitrate as a source of HONO was recently also proposed in the atmosphere over snow (Beine et al., 2001, 2002; Dibb et al., 2002; Honrath et al., 2002; Zhou et al., 2001), ground and vegetation surfaces (Zhou et al., 2002a), to explain high day-time concentrations of HONO. In addition, a photolytic HONO source by photolysis of nitrate was proposed for glass surfaces (Zhou et al., 2002b, 2003). However, based on the results from the present study, the photolysis of nitrate can be excluded. A significant HONO formation was also observed in SAPHIR when light with wavelengths $<370 \mathrm{~nm}$ was blocked by the filter foil. Since the weak absorption band of nitrate at $\sim 300 \mathrm{~nm}\left(\varepsilon=\sim 71 \mathrm{~mol}^{-1} \mathrm{~cm}^{-1}\right.$, Meyerstein and Treinin, 1961) was found to be responsible for nitrite and $\mathrm{NO}_{2}$ formation in solution (Wagner et al., 1980), and since nitrate absorption does not extend to wavelengths $>370 \mathrm{~nm}$, no significant photolytic HONO formation would have been expected in the experiments with the filter foil. In the present study a good correlation of the photolytic HONO formation with the photolysis frequency of $\mathrm{NO}_{2}$ was found. This can be demonstrated by the excellent agreement between measurements and model calculation using Eq. (1) for the experiments with and without the filter foil (see e.g. Figs. 1 and 2). From the wavelength dependence of the studied photoenhanced HONO formation in the SAPHIR chamber and from the transmission characteristics of the filter foil, photochemical processes at wavelengths exclusively $<370 \mathrm{~nm}$ and exclusively $>420 \mathrm{~nm}$ can be excluded, since HONO formation should have been reduced by two orders of magnitude in the first case and only by $15 \%$ in the second case, caused by the transmission of the filter foil.

In a recent study of Saliba et al. (2001) it was shown by infrared spectroscopy that adsorbed nitric acid should be almost undissociated on surfaces up to a water coverage of the surface of three formal monolayers. However, photolysis of adsorbed $\mathrm{HNO}_{3}$ can only explain the experimental observations, if the relative shape of the UV absorption spectra of undissociated adsorbed $\mathrm{HNO}_{3}$ is significantly different to the spectra of undissociated gaseous $\mathrm{HNO}_{3}$ (Sander et 
al., 2003). The UV absorption cross section of $\mathrm{HNO}_{3} / \mathrm{H}_{2} \mathrm{O}$ films on $\mathrm{Al}_{2} \mathrm{O}_{3}$ surfaces was recently measured by Berland et al. (1996). Unfortunately, only the $\pi \rightarrow \pi *$ band at $\sim 200 \mathrm{~nm}$ was investigated. For the oscillator strength of the band no significant difference between thin films of nitric acid and gaseous nitric acid was observed. In addition, the band was shifted by only $\sim 10 \mathrm{~nm}$ to longer wavelength for the thin film. Accordingly, it can be concluded that adsorbed undissociated $\mathrm{HNO}_{3}$ has a similar UV absorption spectrum compared to gaseous nitric acid. As an upper limit of the long wavelength photolysis of adsorbed $\mathrm{HNO}_{3}$ in the spectral range of the SAPHIR chamber, it was assumed that the absorption cross section of adsorbed $\mathrm{HNO}_{3}$ is similar to that of gaseous $\mathrm{HNO}_{3}$ given by Sander et al. (2003) and remains constant in the wavelength range $350-420 \mathrm{~nm}$ with the lowest value given for gaseous $\mathrm{HNO}_{3}$ for $350 \mathrm{~nm}$. Under this assumption, HONO formation by photolysis of adsorbed $\mathrm{HNO}_{3}$ should be reduced by a factor of $>50$ by the use of the filter foil. However, only a reduction of a factor of 3 was observed in the experiments. In addition, by using the obviously overestimated absorption cross sections mentioned above, a $\mathrm{HNO}_{3}$ adsorption of 10 monolayers, which is an unrealistic high value for the SAPHIR chamber and a quantum yield of 1 for $\mathrm{HONO}$ formation by $\mathrm{HNO}_{3}$ photolysis, which is two orders of magnitude higher than the effective quantum yield for nitrite formation by nitrate photolysis in solution at pH 4-7 (Mark et al., 1996), the rate of HONO formation in the chamber would be still more than one order of magnitude lower than the measured one in the experiments with the filter foil. Another argument against the photolysis of adsorbed undissociated $\mathrm{HNO}_{3}$ is the observation, that photolytic HONO formation still increased for relative humidities of $>50 \%$. For the highest relative humidities of $\sim 80 \%$ it can be expected, that $\mathrm{HNO}_{3}$ will dissociate to nitrate (Saliba et al., 2001; Svensson and Ljungström, 1987), which was excluded as a precursor of HONO in the chamber (see above). Accordingly, it is proposed that adsorbed nitric acid does not represent the precursor of $\mathrm{HONO}$ formed during the irradiation of the chamber, although this cannot be completely excluded, since the UV absorption spectra of adsorbed nitric acid on Teflon surfaces is unknown.

In the study of Killus and Whitten (1990) elevated background reactivity was documented for Teflon chambers after experiments with high nitric acid concentrations. Based on these results it might be possible that the precursor of $\mathrm{HONO}$ is formed by a reaction of $\mathrm{HNO}_{3}$ with unknown compounds in the fibre structure of the Teflon foil. Candidates for these compounds might be higher molecular organics from the production of the Teflon material, which are oxidised by $\mathrm{HNO}_{3}$. Thus, the hypothetical precursurs might be organic nitrates, nitrites, nitroaromatics, pernitric acids etc., formed in the Teflon foil. From the experiments with the filter foil it can be concluded that the precursor of HONO should photolyse in a similar wavelength range as $\mathrm{NO}_{2}$. In contrast it cannot photolyse in the spectral range in which nitrate or gaseous
$\mathrm{HNO}_{3}$ absorb.

The water dependence of the photolytic HONO source was described by a quadratic function (see Eq. 1), which resembles the dependence of water uptake on FEP Teflon shown in Fig. 7 of Svensson et al. (1987). Based on the observed humidity dependence of the photolytic HONO source it can be speculated that either only the dissociated form of the precursor photolyses or that HONO is formed by a reaction of photolysis products with adsorbed water. One candidate might be a hypothetical fast reaction of an excited $\mathrm{NO}_{2}$ molecule, formed in the photolysis of the unknown precursor, with water. In contrast, the reaction of ground state $\mathrm{NO}_{2}$ molecules with adsorbed water cannot explain the experimental findings, since no enhancement of the photolytic HONO formation was observed with increasing $\mathrm{NO}_{2}$ concentration. Since it is well known that molecules diffuse through Teflon material, it can be expected that $\mathrm{HNO}_{3}$ will react with the postulated organic compounds also on the internal surface of the Teflon foil. Since $\mathrm{HNO}_{3}$ is formed as the end product of $\mathrm{NO}_{\mathrm{x}}$ in most experiments and since efficient deposition of $\mathrm{HNO}_{3}$ on the wall can be expected, the concentration of the precursor and accordingly the photolytic HONO source will probably not decrease significantly, as observed over a period of more than two years in the chamber. However, this argument holds only, if the concentration of the speculated organic compound, which forms the precursor of $\mathrm{HONO}$ by reaction with $\mathrm{HNO}_{3}$, is high enough. However, to estimate the loss fraction from a reservoir of a HONO producing species in the Teflon film we calculate a typical HONO production of $\sim 7 \times 10^{19}$ molecules $(1.7 \mathrm{mg} \mathrm{N})$ in one $5 \mathrm{~h}$ experiment $(50 \%$ relative humidity, $\left.\mathrm{J}\left(\mathrm{NO}_{2}\right)=5 \times 10^{-3} \mathrm{~s}^{-1}\right)$. If the source were in the bulk of the FEP wall material the loss of nitrogen corresponds to only $0.02 \mathrm{ppm}$ mass fraction of the inner FEP wall (approx. $80 \mathrm{~kg}$ ).

In conclusion, although several pathways of the photolytic HONO formation discussed in the literature could be excluded, e.g. a photoenhancement of the reaction of $\mathrm{NO}_{2}$ and $\mathrm{H}_{2} \mathrm{O}$ or a photolysis of nitrate, the precursor of $\mathrm{HONO}$ formed photolytically in the SAPHIR chamber was not identified. Accordingly further work is needed to clarify this process which is of paramount importance for the radical balance of simulation chambers.

It was shown that HONO production in the simulation chamber SAPHIR can be predicted with good precision for longer time intervals. An unexplained change in the HONO production was observed in August 2002, i.e. a change of the parameter $a_{1}$ in Eq. (1) by a factor of 1.8. Therefore, we conclude that the chamber related (photolytic) HONO source must be quantified in regular intervals to confirm its stability. Since Eq. (1) is an empirical parameterisation of the HONO source in the SAPHIR chamber, we do not advise the application of our parameters in other chambers. However, Eq. (1) can be used to compare HONO formation rates measured in other simulation chambers by appropriately scaling it, taking into account the SAPHIR S/V ratio of $1 \mathrm{~m}^{-1}$. When compar- 


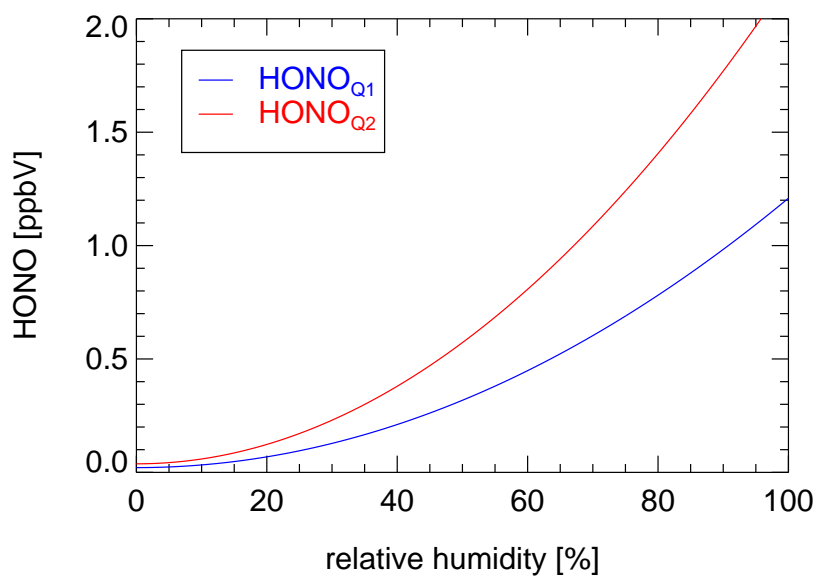

Fig. 5. Predicted stationary HONO mixing ratios inside SAPHIR calculated with Eq. (1) and parameters from Table 4 for $\mathrm{T}=295 \mathrm{~K}$.

ing the estimated HONO formation rates from other chamber experiments (Carter et al, 1981; Carter et al., 1982; Glasson and Dunker, 1989; Kleffmann, 2004 ${ }^{3}$ ) with values calculated from Eq. (1) under the same experimental condition, lower HONO formation is observed in the SAPHIR chamber. This is most probably caused by the much lower educt concentrations used in the SAPHIR chamber compared to other simulation chambers.

The prediction capability of Eq. (1) can now be used to characterise the radical production in SAPHIR and compare it to radical production in ambient air to show that SAPHIR is a suitable tool for atmospheric simulation experiments at ambient conditions. If the photolytic production of $\mathrm{HONO}$ (Reaction R3) is the dominant source and the photolysis of HONO (Reaction R1) the dominant sink of HONO in the SAPHIR chamber, then a simple photostationary state calculation of $\mathrm{HONO}$ can be performed:

$[\mathrm{HONO}]=\frac{\mathrm{P}(\mathrm{HONO})}{\mathrm{J}(\mathrm{HONO})}=\frac{\mathrm{S}(\mathrm{HONO})_{\text {SAPHIR }}}{\mathrm{J}(\mathrm{HONO})}$

Taking into account the strong correlation between $\mathrm{J}\left(\mathrm{NO}_{2}\right)$ and J(HONO) (Kraus and Hofzumahaus, 1998), the steady state concentration of HONO can be calculated:

$\mathrm{J}(\mathrm{HONO})=\mathrm{J}\left(\mathrm{NO}_{2}\right) / 5.8$

$[\mathrm{HONO}]_{i}=a_{i} \times 5.8 \times\left(1+\left(R H / R H_{0}\right)^{2}\right) \times e^{-T_{0} / T}$

$\mathrm{P}(\mathrm{OH})_{\mathrm{HONO}}=[\mathrm{HONO}]_{i} \times \mathrm{J}(\mathrm{HONO})=\mathrm{S}(\mathrm{HONO})_{i}$

Equation (4) was used to calculate steady state HONO concentrations for different humidities at $295 \mathrm{~K}$ in the SAPHIR chamber. The results are shown in Fig. 5. These calculations emphasise the difference between the two parameters $a_{1}$ and $a_{2}$ in Table 4 which distinguish between the

\footnotetext{
${ }^{3}$ Kleffmann, J.: not published results from the EUPHORE chamber in Valencia/Spain, 2004.
}

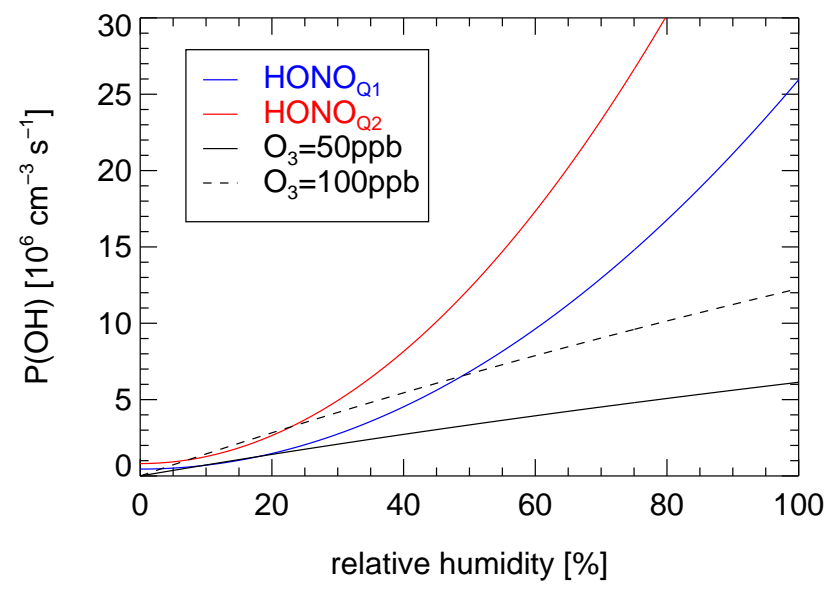

Fig. 6. Production of $\mathrm{OH}$ radicals inside SAPHIR from HONO photolysis and from ozone photolysis calculated with Eqs. (1), (5), (6) and parameters from Table 4 for $\mathrm{T}=295 \mathrm{~K}, \mathrm{~J}\left(\mathrm{NO}_{2}\right)=5 \times 10^{-3} \mathrm{~s}^{-1}$, and $\mathrm{J}\left(\mathrm{O}^{1} \mathrm{D}\right)=1.5 \times 10^{-5} \mathrm{~s}^{-1}$.

time before August, 2002, and afterwards. The calculated mixing ratios are in good agreement with LOPAP HONO measurements (see Figs. 1 and 2). Using typical values for $\mathrm{J}\left(\mathrm{NO}_{2}\right)$ and $\mathrm{J}\left(\mathrm{O}^{1} \mathrm{D}\right)$ of $5 \times 10^{-3} \mathrm{~s}^{-1}$ and $1.5 \times 10^{-5} \mathrm{~s}^{-1}$ respectively, Eq. (1) and (5) can be used to compare the production of $\mathrm{OH}$ from $\mathrm{HONO}$ photolysis to the production rate from ozone photolysis $\mathrm{P}(\mathrm{OH})_{\mathrm{O}_{3}}$, Eq. (6), determined by Reactions (R7) to (R10):

$$
\begin{aligned}
& \mathrm{P}(\mathrm{OH})_{\mathrm{O}_{3}}=\frac{2 \times\left[\mathrm{O}_{3}\right] \times \mathrm{J}\left(\mathrm{O}^{1} \mathrm{D}\right) \times k_{8} \times\left[\mathrm{H}_{2} \mathrm{O}\right]}{k_{8} \times\left[\mathrm{H}_{2} \mathrm{O}\right]+k_{9} \times\left[\mathrm{N}_{2}\right]+k_{10} \times\left[\mathrm{O}_{2}\right]} \\
& \mathrm{O}_{3}+h v \longrightarrow \mathrm{O}^{1} \mathrm{D}+\mathrm{O}_{2} \\
& \mathrm{O}^{1} \mathrm{D}+\mathrm{H}_{2} \mathrm{O} \longrightarrow 2 \mathrm{OH} \\
& \mathrm{O}^{1} \mathrm{D}+\mathrm{N}_{2} \longrightarrow \mathrm{O}^{3} \mathrm{P}+\mathrm{N}_{2} \\
& \mathrm{O}^{1} \mathrm{D}+\mathrm{O}_{2} \longrightarrow \mathrm{O}^{3} \mathrm{P}+\mathrm{O}_{2}
\end{aligned}
$$

With steady-state concentrations of HONO taken from Fig. 5, the OH production from HONO photolysis is compared to $\mathrm{OH}$ production rates calculated with typical tropospheric ozone concentrations of 50 and 100 ppbV in Fig. 6. The total $\mathrm{OH}$ production in SAPHIR for these illumination conditions is in the region of 1 to 30 times $10^{6} \mathrm{~cm}^{-3} \mathrm{~s}^{-1}$ or $150-4500 \mathrm{pptV} / \mathrm{h}$. In the range $5 \%$ to $30 \%$ relative humidity, both processes have approximately the same contribution. Above $60 \%$ or below $5 \%$ relative humidity, $\mathrm{OH}$ production by HONO photolysis is 2 to 6 times larger than by ozone photolysis.

The calculated HONO concentrations and $\mathrm{OH}$ production rates can be compared to ambient measurements. Recent studies show HONO mixing ratios in the range 50-500 pptV (Kleffmann et al., 2002, 2003, 2005² ; Ren et al., 2003, Zhou 
et al., 2002a) during daylight. In addition $\mathrm{OH}$ production rates of 200-1800 pptV/h were estimated for the atmosphere (Kleffmann et al., 2005²; Ren et al., 2003; Zhou et al., 2002a). This comparison shows, that HONO photolysis is comparable to or dominating the $\mathrm{OH}$ production from ozone photolysis inside the SAPHIR chamber but also outside in ambient air (e.g. Kleffmann et al., 2005²; Ren et al., 2003; Vogel et al., 2003). However, it should be noted that the mechanism of the photolytic HONO formation in SAPHIR might be entirely different from the mechanism in the ambient atmosphere.

\section{Summary}

It was shown that the photoenhanced HONO production in the simulation chamber SAPHIR depends exclusively on solar irradiation, relative humidity, and temperature. The rate of HONO production can be predicted with good precision by an empirical parameterisation including the photolysis frequency of $\mathrm{NO}_{2}, \mathrm{~J}\left(\mathrm{NO}_{2}\right)$, as a scaling factor for solar irradiation, a square dependence on relative humidity, and exponential growth with temperature. Photolysis of HONO seems to be the only source of $\mathrm{NO}$ and $\mathrm{OH}$ in the flushed-out simulation chamber. The good reproducibility of the HONO production rate and its independence on other boundary conditions, especially on $\mathrm{NO}_{2}$ concentration, allows the inclusion of this process in further studies which depend on the quantitative understanding of the $\mathrm{HO}_{\mathrm{x}}$ radical budget or the nitrogen oxide budget.

Acknowledgement. This work was supported by the BMBF German Atmospheric Research Program AFO2000, within its subproject IDEC (Integrated Data Archive of Atmospheric Chemical Standard Scenarios for the Evaluation of Chemistry-Transport Models) under grant 07ATF02.

Edited by: R. Cox

\section{References}

Akimoto, H., Takagi, H., and Sakamaki, F.: Photoenhancement of the Nitrous Acid Formation in the Surface Reaction of Nitrogen Dioxide and Water Vapour: Extra Radical Source in Smog Chamber Experiments, Int. J. Chem. Kinet., 19, 539-551, 1987.

Alicke, B., Platt, U., and Stutz, J.: Impact of Nitrous Acid Photolysis on the Total Hydroxy Radical Budget During the Limitation of Oxidant Production/Pianura Padana Produzione di Ozono Study in Milan, J. Geophys. Res., 107(D22), 8196, doi:10.1029/2000JD000075, 2002.

Alicke, B., Geyer, A., Hofzumahaus, A., Holland, F., Konrad, S., Pätz., H. W., Schäfer, J., Stutz, J., Volz-Thomas, A., and Platt, U.: OH Formation by HONO Photolysis During the BERLIOZ Experiment, J. Geophys. Res., 108(D4), 8247, doi:10.1029/2001 JD000579, 2003.

Appel, B. R., Winer, A. M., Tokiwa, Y., and Biermann, H. W.: Comparison of Atmospheric Nitrous Acid Measurements by Annular
Denuder and Optical Absorption Systems, Atmos. Environ., 24 A, 611-616, 1990.

Aumont, B., Chervier, F., and Laval, S.: Contribution of HONO Sources to the $\mathrm{NO}_{\mathrm{X}} / \mathrm{HO}_{\mathrm{X}} / \mathrm{O}_{3}$ Chemistry in the Polluted Boundary Layer, Atmos. Environ., 37, 487-498, 2003.

Beine, H. J., Allegrini, I., Sparapani, R., Ianniello, A., and Valentini, F.: Three Years of Springtime Trace Gas and Particle Measurements at Ny-Ålesund, Svalbard, Atmos. Environ., 35, 3645 3658, 2001.

Beine, H. J., Dominé, F., Simpson, W., Honrath, R. E., Sparapani, R., Zhou, X., and King, M.: Snow-pile and Chamber Experiments during the Polar Sunrise Experiment, Alert 2000: Exploration of Nitrogen Chemistry, Atmos. Environ., 36, 2707-2719, 2002.

Berland, B. S., Foster, K. L., Tolbert, M. A., and George, S. M.: UV Absorption Spectra of $\mathrm{H}_{2} \mathrm{O} / \mathrm{HNO}_{3}$ Films, Geophys. Res. Lett., 23, 2757-2760, 1996

Bohn, B. and Zilken, H.: Model-aided and Radiometric Determination of Photolysis Frequencies in a Sunlit Atmosphere Simulation Chamber, Atmos. Chem. Phys., 5, 191-206, 2005,

SRef-ID: 1680-7324/acp/2005-5-191.

Bohn, B., Rohrer, F., Brauers, T., and Wahner, A.: Actinometric Measurements of $\mathrm{NO}_{2}$ Photolysis Frequencies in the Atmosphere Simulation Chamber SAPHIR, Atmos. Chem. Phys., 5, 493-503, 2005,

\section{SRef-ID: 1680-7324/acp/2005-5-493.}

Carter, W. P. L., Atkinson, R., Winer, A. M., and Pitts Jr., J. N.: Evidence for Chamber-Dependent Radical Source: Impact on Kinetic Computer Models for Air Pollution, Int. J. Chem. Kinet., 13, 735-740, 1981.

Carter, W. P. L., Atkinson, R., Winer, A. M., and Pitts Jr., J. N.: Experimental Investigation of Chamber-Dependent Radical Source, Int. J. Chem. Kinet., 14, 1071-1103, 1982.

Coe, H., Jones, R. L., Colin, R., Carleer, M., Harrison, R. M., Peak, J., Plane, J. M. C., Smith, N., Allan, B., Clemitshaw, K. C., Burgess, R. A., Platt, U., Etzkorn, T., Stutz, J., Pommereau, J.-P., Goutail, F., Nunes-Pinharanda, M., Simon, P., Hermans, C., and Vandaele. A.-C.: A Comparison of Differential Optical Absorption Spectrometers for Measurement of $\mathrm{NO}_{2}, \mathrm{O}_{3}, \mathrm{SO}_{2}$ and HONO, in: Proceedings of EUROTRAC Symposium'96: Transport and Transformation of Pollutants, edited by: Borrell, P. M., Borrell, P., Cvitaš, T., Kelly, K., Seiler, W., ISBN 185312498 2, Computational Mechanics Publications, Southampton, 757-762, 1997.

Davis, D., Nowak, J. B., Chen, G., Buhr, M., Arimoto, R., Hogan, A., Eisele, E., Mauldin, L., Tanner, D., Shetter, R., Lefer, B., and McMurry, P.: Unexpected High Levels of NO Observed at South Pole, Geophys. Res. Lett., 28, 3625-3628, 2001.

Dibb, J. E., Arsenault, M., Peterson, M. C., and Honrath, R. E.: Fast Nitrogen Oxide Photochemistry in Summit, Greenland Snow, Atmos. Environ., 36, 2501-2511, 2002.

Ehhalt, D. H. and Rohrer, F.: Dependence of the $\mathrm{OH}$ Concentration on Solar UV, J. Geophys. Res., 105, 3565-3571, 2000.

Fahey, D. H., Eubank, C. S., Hübler, G., and Fehsenfeld, F. C.: Evaluation of a Catalytic Reduction Technique for the Measurement of Total Reactive Odd-Nitrogen $\mathrm{NO}_{\mathrm{y}}$ in the Atmosphere, J. Atmos. Chem., 3, 435-468, 1985.

Febo, A., Perrino, C., and Allegrini, I.: Measurement of Nitrous Acid in Milan, Italy, by DOAS and Diffusion Denuders, Atmos. 
Environ., 30, 3599-3609, 1996.

Finlayson-Pitts, B. J., Wingen, L. M., Sumner, A. L., Syomin, D., and Ramazan, K. A.: The Heterogeneous Hydrolysis of $\mathrm{NO}_{2}$ in Laboratory Systems and in Outdoor and Indoor Atmospheres. An Integrated Mechanism, Phys. Chem. Chem. Phys., 5, 223-242, 2003.

George, C., Strekowski, R. S., Kleffmann, J., Stemmler, K., and Ammann, M.: Photoenhanced Uptake of Gaseous $\mathrm{NO}_{2}$ on Solid Organic Compounds: A Photochemical Source of HONO, Faraday Discuss., 130, 1-16, doi:10.1039/b417888m, 2005.

Glasson, W. A. and Dunker, A. M.: Investigation of Background Radical Sources in a Teflon-Film Irradiation Chamber, Environ. Sci. Technol., 23, 970-978, 1989.

Gutzwiller, L., Arens, F., Baltensperger, U., Gäggeler, H. W., and Ammann, M.: Significance of Semivolatile Diesel Exhaust Organics for Secondary HONO Formation, Environ. Sci. Technol., 36, 677-682, 2002.

Harris, G. W., Carter, W. P. L., Winer, A. M., Pitts Jr., J. N., Platt, U., and Perner, D.: Observation of Nitrous Acid in the Los Angeles Atmosphere and Implications for Predictions of Ozone-Precursor Relationships, Environ. Sci. Technol., 16, 414-419, 1982.

Harrison, R. M., Peak, J. D., and Collins, G. M.: Tropospheric Cycle of Nitrous Acid, J. Geophys. Res., 101, 14 429-14 439, 1996.

Heland, J., Kleffmann, J., Kurtenbach, R., and Wiesen, P.: A New Instrument to Measure Gaseous Nitrous Acid (HONO) in the Atmosphere, Environ. Sci. Technol., 35, 3207-3212, 2001.

Hofzumahaus, A., Kraus, A., and Müller, M.: Solar Actinic Flux Spectroradiometry: A New Technique to Measure Photolysis Frequencies in the Atmosphere, Appl. Opt., 38, 4443-4460, 1999.

Honrath, R. E., Peterson, M. C., Guo, S., Dibb, J. E., Shepson, P. B., and Campbell, B.: Evidence of $\mathrm{NO}_{\mathrm{x}}$ Produduction within or upon Ice Particles in the Greenland Snowpack, Geophys. Res. Lett., 26, 695-698, 1999.

Honrath, R. E., Guo, S., Peterson, M. C., Dziobak, M. P., Dibb, J. E., and Arsenault, M. A.: Photochemical Production of Gas Phase $\mathrm{NO}_{\mathrm{x}}$ from Ice Crystal $\mathrm{NO}_{3}^{-}$, J. Geophys. Res., 105, 24 183-24 190, 2000.

Honrath, R. E., Y. Lu, Peterson, M. C., Dibb, J. E., Arsenault, M. A., Cullen, N. J., and Steffen, K.: Vertical Fluxes of $\mathrm{NO}_{\mathrm{x}}, \mathrm{HONO}$, and $\mathrm{HNO}_{3}$ above the Snowpack at Summit, Greenland, Atmos. Environ., 36, 2629-2640, 2002.

Jenkin, M. E., Cox, R. A., and Williams, D. J.: Laboratory Studies of the Kinetics of Formation of Nitrous Acid from the Thermal Reaction of Nitrogen Dioxide and Water Vapour, Atmos. Environ., 22, 487-498, 1988.

Jones, A. E., Weller, R., Wolff, E. W., and Jacobi, H.-W.: Speciation and Rate of Photochemical $\mathrm{NO}$ and $\mathrm{NO}_{2}$ Production in Antarctic Snow, Geophys. Res. Lett., 27, 345-348, 2000.

Jones, A. E., Weller, R., Anderson, P. S., Jacobi, H.-W., Wolff, E. W., Schrems, O., and Miller, H.: Measurements of $\mathrm{NO}_{\mathrm{x}}$ Emissions from the Antarktic Snowpacks, Geophys. Res. Lett., 28, 1499-1502, 2001.

Killus, J. P. and Whitten, G. Z.: Background Reactivity in Smog Chambers, Int. J. Chem. Kinet., 22, 547-575, 1990.

Kleffmann, J., Becker, K. H., and Wiesen, P.: Heterogeneous $\mathrm{NO}_{2}$ Conversion Processes on Acid Surfaces: Possible Atmospheric Implications, Atmos. Environ., 32, 2721-2729, 1998.
Kleffmann, J., Heland, J., Kurtenbach, R., Lörzer, J. C., and Wiesen, P.: A New Instrument (LOPAP) for the Detection of Nitrous Acid (HONO), Environ. Sci. Pollut. Res., 9 (special issue 4), 48-54, 2002.

Kleffmann, J., Kurtenbach, R., Lörzer, J. C., Wiesen, P., Kalthoff, N., Vogel, B., and Vogel, H.: Measured and Simulated Vertical Profiles of Nitrous Acid, Part I: Field Measurements, Atmos. Environ, 37, 2949-2955, 2003.

Kleffmann, J., Gavriloaiei, T., Hofzumahaus, A., Holland, F., Koppmann, R., Rupp, L., Schlosser, E., Siese, M., and Wahner, A.: Daytime Formation of Nitrous Acid: A Major Source of OH Radicals in a Forest, Geophys. Res. Lett., 32, L05818, doi:10.1029/2005GL022524, 2005.

Kraus, A. and Hofzumahaus, A.: Field Measurements of Atmospheric Photolysis Frequencies for $\mathrm{O}_{3}, \mathrm{NO}_{2}, \mathrm{HCHO}, \mathrm{CH}_{3} \mathrm{CHO}$, $\mathrm{H}_{2} \mathrm{O}_{2}$, and $\mathrm{HONO}$ by UV Spectroradiometry, J. Atmos. Chem., 31, 161-180, 1998.

Mark, G., Korth, H.-G., Schuchmann, H.-P., and von Sonntag, C.: The Photochemistry of Aqueous Nitrate Ion Revised, Photochem. Photobiol., 101, 89-103, 1996.

Meyerstein, D. and Treinin, A.: Absorption Spectra of $\mathrm{NO}_{3}^{-}$in Solution, Trans. Faraday Soc., 57, 2104-2112, 1961.

Müller, Th., Dubois, R., Spindler, G., Brüggemann, E., Ackermann, R., Geyer, A., and Platt, U.: Measurements of Nitrous Acid by DOAS and Diffusion Denuders: A Comparison, in: Proceedings of EUROTRAC Symposium'98: Transport and Chemical Transformation in the Troposphere, Volume I, edited by: Borrell, P. M. and Borrell, P., ISBN 1-85312-743-4, WITPress, Southampton, 345-349, 1999.

Pitts Jr., J. N., Grosjean, D., van Cauwenberghe, K., Schmid, J. P., and Fitz, D. R.: Photooxidation of Aliphatic Amines under Simulated Atmospheric Conditions: Formation of Nitrosamines, Nitramines, Amides, and Photochemical Oxidant, Environ. Sci. Technol., 12, 946-953, 1978.

Pitts Jr., J. N., Sanhueza, E., Atkinson, R., Carter, W. P. L., Winer, A. M., Harris, G. W., and Plum, C. N.: An Investigation of the Dark Formation of Nitrous Acid in Environmental Chambers, Int. J. Chem. Kinet., 16, 919-939, 1984.

Ren, X., Harder, H., Martinez, M., Lesher, R. L., Oliger, A., Simpas, J. B., Brune, W. H., Schwab, J. J., Demerjian, K. L., He, Y., Zhou, X., and Gao, H.: $\mathrm{OH}$ and $\mathrm{HO}_{2}$ Chemistry in Urban Atmosphere of New York City, Atmos. Environ, 37, 3639-3651, 2003.

Rohrer, F., Brüning, D., Grobler, E. S., Weber, M., Ehhalt, D. H., Neubert, R., Schübler, W., and Levin, L.: Mixing Ratios and Photostationary State of $\mathrm{NO}$ and $\mathrm{NO}_{2}$ Observed During the POPCORN Field Campaign at a Rural Site in Germany, J. Atmos. Chem., 31, 119-137, 1998.

Sakamaki, F., Hatakeyama, S., and Akimoto, H.: Formation of Nitrous Acid and Nitric Oxide in the Heterogeneous Dark Reaction of Nitrogen Dioxide and Water Vapour in a Smog Chamber, Int. J. Chem. Kinet., 15, 1013-1029, 1983.

Sakamaki, F. and Akimoto, H.: HONO Formation as Unknown Radical Source in Photochemical Smog Chambers, Int. J. Chem. Kinet., 20, 111-116, 1988.

Saliba, N. A., Yang, H., and Finlayson-Pitts, B. J.: Reaction of Gaseous Nitric Oxide with Nitric Acid on Silica Surfaces in the Presence of Water at Room Temperature, J. Phys. Chem. A, 105, 10339-10346, 2001. 
Sander, S. P., Friedl, R. R., Golden, D. M., Kurylo, M. J., Huie, R. E., Orkin, V. L., Moortgat, G. K., Ravishankara, A. R., Kolb, C. E., Molina, M. J., and Finlayson-Pitts, B. J.: Chemical Kinetics and Photochemical Data for Use in Stratospheric Modeling, JPL Publication 02-25, Pasadena, California, 2003.

Svensson, R., Ljungström, E., and Lindqvist, O.: Kinetics of the Reaction between Nitrogen Dioxide and Water Vapour, Atmos. Environ., 21, 1529-1539, 1987.

Syomin, D. A. and Finlayson-Pitts, B. J.: HONO Decomposition on Borosilicate Glass Surfaces: Implications for Environmental Chamber Studies and Field Experiments, Phys. Chem. Chem. Phys., 5 (advanced article), doi:10.1039/b309851f, 2003.

Taira, M. and Kanda, Y.: Continous Generation System for LowConcentration Gaseous Nitrous Acid, Anal. Chem., 62, 630-633, 1990.

Vogel, B., Vogel, H., Kleffmann, J., and Kurtenbach, R.: Measured and Simulated Vertical Profiles of Nitrous Acid, Part II - Model Simulations and Indications for a Photolytic Source, Atmos. Environ, 37, 2957-2966, 2003.

Wagner, I., Strehlow, H., and Busse, G.: Flash Photolysis of Nitrate Ions in Aqueous Solutions, Z. Phys. Chem., 123, 1-33, 1980.
Wang, L., Milford, J. B., and Carter, W. P. L.: Reactivity Estimates for Aromatic Compounds. Part 1. Uncertainty in ChamberDerived Parameters, Atmos. Environ., 34, 4337-4348, 2000.

Zhou, X., Beine, H. J., Honrath, R. E., Fuentes, J. D., Simpson, W., Shepson, P. B., and Bottenheim, J. W.: Snowpack Photochemical Production of HONO: a Major Source of $\mathrm{OH}$ in the Arctic Boundary Layer in Springtime, Geophys. Res. Lett., 28, 4087 4090, 2001.

Zhou, X., Civerolo, K., Dai, H., Huang, G., Schwab, J., and Demerjian, K.: Summertime Nitrous Acid Chemistry in the Atmospheric Boundary Layer at a Rural Site in New York State, J. Geophys. Res., 107(D21), 4590, doi:10.1029/2001JD001539, 2002a.

Zhou, X., He, Y., Huang, G., Thornberry, T. D., Carroll, M. A., and Bertman, S. B.: Photochemical Production of Nitrous Acid on Glass Sample Manifold Surface, Geophys. Res. Lett., 29(14), 10.1029/2002GL015080, 2002b.

Zhou, X., Gao, H., He, Y., Huang, G., Bertman, S., Civerolo, K., and Schwab, J.: Nitric Acid Photolysis on Surfaces in Low-NO Environments: Significant Atmospheric Implications, Geophys. Res. Lett., 30(23), 2217, doi:10.1029/2003GL018620, 2003. 